\title{
Regulation of the vascular endothelial growth factor (VEGF) receptor Flk-1/KDR by estradiol through VEGF in uterus
}

\author{
M A J Hervé ${ }^{1}$, G Meduri ${ }^{1}$, F G Petit ${ }^{1}$, T S Domet ${ }^{1}$, G Lazennec ${ }^{3}$, \\ S Mourah ${ }^{2}$ and $M$ Perrot-Applanat ${ }^{1}$ \\ 'IINSERM U553, Institut Universitaire d'Hématologie, Hôpital Saint-Louis/Bâtiment INSERM, 1 avenue Claude Vellefaux, 75010 Paris, France \\ ${ }^{2}$ INSERM U716, Institut Universitaire d'Hématologie, Hôpital Saint-Louis/Bâtiment INSERM, 1 avenue Claude Vellefaux, 75010 Paris, France \\ ${ }^{3}$ Unité INSERM 540, Montpellier, France \\ (Requests for offprints should be addressed to M Perrot-Applanat; Email: applanat@chu-stlouis.fr)
}

\begin{abstract}
The induction of vascular endothelial growth factor (VEGF) expression by $17 \beta$-estradiol $\left(\mathrm{E}_{2}\right)$ in many target cells, including epithelial cells, fibroblasts and smooth muscle cells, suggests a role for this hormone in the modulation of angiogenesis and vascular permeability. We have already described a cyclic increase in Flk-1/KDRexpressing capillaries in the human endometrium during the proliferative and mid-secretory phases, strongly suggestive of an $\mathrm{E}_{2}$ effect on Flk-1/KDR expression in the endometrial capillaries. However, it is unclear whether these processes are due to a direct effect of $\mathrm{E}_{2}$ on endothelial cells. Using immunohistochemistry, we report an increase in Flk-1/KDR expression in endometrial capillaries of ovariectomized mice treated with $\mathrm{E}_{2}$, or both $\mathrm{E}_{2}$ and progesterone. This process is mediated through estrogen receptor (ER) activation. In vitro experiments
\end{abstract}

using quantitative RT-PCR analysis demonstrate that Flk-1/KDR expression was not regulated by $E_{2}$ in human endothelial cells from the microcirculation (HMEC-1) or macrocirculation (HUVEC), even in endothelial cells overexpressing ER $\alpha$ or ER $\beta$ after ER-mediated adenovirus infection. In contrast, Flk-1/KDR expression was up-regulated by VEGF itself, in a time- and dosedependent manner, with the maximal response at $10 \mathrm{ng} /$ ml. Thus, we suggest that $E_{2}$ up-regulates Flk-1/KDR expression in vivo in endothelial cells mainly through the modulation of VEGF by a paracrine mechanism. It is currently unknown whether or not the endothelial origin might account for differences in the $\mathrm{E}_{2}$-modulation of VEGF receptor expression, particularly in relation to the vascular bed of sex steroid-responsive tissues.

Journal of Endocrinology (2006) 188, 91-99

\section{Introduction}

Hormonally controlled angiogenesis is fundamental for endometrial development and the differentiation necessary for implantation, as well as for the uterine changes associated with pregnancy (Giudice 1996, PerrotApplanat 2000). Physiological angiogenesis is also required to support endometrial regeneration after shedding of the uterine surface in the absence of implantation and to support the proliferation of the human endometrium during the menstrual cycle under the control of estradiol $\left(E_{2}\right)$ and progesterone. Models of endometrial angiogenesis in the proliferative phase describe the growth of vasculature under the influence of estrogen, while the secretory phase involves growth of the coiled arteries mediated by progesterone. Previous studies have demonstrated that $E_{2}$ increases the secretion of vascular endothelial growth factor (VEGF) in uterine cells (Cullivan-Bove \& Koos 1993, Shifren et al. 1996, Bausero et al. 1998); this factor has emerged as one of the central regulators of the uterine vasculature (see review by Perrot-Applanat 2000).

In vivo, VEGF induces a potent angiogenic response in a variety of models and acts as a vascular permeability factor based on its ability to induce vascular leakage (see reviews by Ferrara \& Davis-Smyth 1997, Ferrara et al. 2003). VEGF is also a survival factor for endothelial cells, preventing apoptosis induced by serum starvation. Molecular cloning of the human VEGF gene has revealed that differential exon splicing generates multiple tissueand function-specific variants containing 121, 165, 189, and 206 amino acids (see review by Ferrara \& DavisSmyth 1997). In most systems, VEGF121 and VEGF165 are the major species expressed, while VEGF189 is only minimally present and VEGF206 is limited to embryonic tissue. In the human endometrium, $\mathrm{E}_{2}$ up-regulates all VEGF isoforms (Shifren et al. 1996, Bausero et al. 1998), while progesterone selectively increases the expression of the VEGF189 isoform (Ancelin et al. 2002). The role of these isoforms is still debated. Also, little is known about 
the effect of $\mathrm{E}_{2}$ on the endothelial cells and on VEGF signaling.

The angiogenic effects of VEGF are believed to be mediated by two tyrosine kinase receptors, Flt-1 (Fms-like tyrosine kinase-1 or VEGFR-1) and Flk-1/KDR (fetal liver kinase/kinase-insert domain receptor or VEGFR-2). These receptors initiate different signaling cascades in endothelial cells (Gille et al. 2001). Flk-1/KDR is now considered to be the main receptor involved in endothelial cell proliferation, migration and survival (Millauer et al. 1993, Ferrara et al. 2003). In contrast, Flt-1 has a decoy effect on VEGF signaling, possibly with variations related to the vascular bed type (Ferrara et al. 2003). Factors regulating Flk-1/KDR expression in vivo in endothelial cells are not clearly defined. In tumors, Flk-1/KDR appears to be regulated by hypoxia, an effect probably mediated by VEGF (Kremer et al. 1997). VEGF and its receptor, Flk-1/KDR, which are expressed in most tissues during embryonic development, are down-regulated in the adult in physiological conditions, except in the reproductive tract (Perrot-Applanat 2000, Ferrara et al. 2003). In the human endometrium, Flk-1/KDR expression in endometrial blood vessels seems to exhibit menstrual cycle-dependent changes, with higher expression in the proliferative and the early or early-mid secretory phases, suggesting that ovarian hormones influence the expression of this receptor in the uterus (Meduri et al. 2000). In vitro studies have shown that Flk-1/KDR expression is regulated by several growth factors (Shen et al. 1998, Ferrara et al. 2003) and by shear stress (Abumiya et al. 2002). Treatment of endothelial cells with $\mathrm{E}_{2}$ directly increases the proliferation and survival of these cells (Morales et al. 1995) through inhibition of apoptosis (Spyridopoulos et al. 1997). However, although $E_{2}$ increases VEGF expression in the endometrium, the relationship between $\mathrm{E}_{2}$ and Flk-1/KDR expression involved in endothelial cell proliferation is poorly understood.

To better ascertain the role of $E_{2}$ in Flk-1/KDR expression, we have examined the role of $\mathrm{E}_{2}$ and the mechanisms controlling Flk-1/KDR expression in a mouse model of angiogenesis. We have also analyzed the expression of the receptor in endothelial cells treated with $\mathrm{E}_{2}$ and VEGF.

\section{Materials and Methods}

\section{Materials}

Reagents for cell culture and PCR were from Gibco (Life Technologies, Cergy-Pontoise, France). Estradiol was purchased from Sigma (Sigma-Aldrich GmbH, Steinheim, Germany). TriZOL isolation kit, Moloney murine leukemia virus (MMLV) reverse transcriptase, and Taq polymerase were from Life Technologies (Cergy-Pontoise, France). Recombinant VEGF was provided by R\&D Systems (Minneapolis, MN, USA).

\section{Mice uteri}

Mice were housed in the animal care facility at the National Institute of Environmental Health Sciences (NIEHS), Research Triangle Park, NC, USA. They were treated in accordance with NIH guidelines for the humane use of animals in research. The generation and characterization of the estrogen receptor $\alpha$ knockout $(\alpha E R K O)$ mice have previously been reported (Couse et al. 1995). Adult wild-type (WT) or $\alpha E R K O$ mice were ovariectomized and rested for two weeks to clear endogenous hormones before any treatment. Mice (4 animals/group) were implanted with a pellet of $\mathrm{E}_{2}$ $(200 \mathrm{ng})$, progesterone $(35 \mathrm{mg}), \mathrm{E}_{2}$ and progesterone or placebo over 21 days. Animals were killed by cervical dislocation and the uterus was removed, fixed in $4 \%$ paraformaldehyde and embedded in paraffin.

Uteri were also dissected out of C57BL6J/129 Svj mice (8- to 12-weeks-old, random cyclic females), fixed in Bouins and embedded in paraffin as previously described (Kurita et al. 2001).

\section{Immunocytochemistry}

Immunological detection of VEGF receptor Flk-1/KDR was performed using the polyclonal rabbit antibody CT128 directed against Flk-1/KDR (1:400 dilution; Millauer et al. 1993), as previously described (Meduri et al. 2000). This antibody has previously been characterized and does not cross-react with other protein kinase receptors. Immunocytochemical staining included overnight incubation at $4{ }^{\circ} \mathrm{C}$ with the primary antibody, followed by incubation with biotinylated anti-rabbit IgG and streptavidin-biotin peroxidase (LSAB2 immunostaining kit Dakopatts, Glostrup, Denmark). Controls included omission of the first antibody and incubation of tissue sections with irrelevant rabbit IgG immunoglobulins. Adjacent sections were incubated with a marker of vascular endothelial cells, the polyclonal anti-Von Willebrand factor (vWF) antibody (Dako, Glostrup, Denmark) (Meduri et al. 2000).

The number of Flk-1/KDR-stained capillaries in each section was determined after identification of the areas containing the highest number of stained capillaries at low power magnification, as previously described (Meduri et al. 2000). Counts of individual immunostained capillaries were performed at higher magnification $(\times 16$ objective, $0.322 \mathrm{~mm}^{2}$ per field), using a stereomicroscope (Leitz, Orthoplan) equipped with a CDD video camera. Five different fields in each section were digitized by image analysis and computerized using the Histolab program (Microvision, Evry, France). Capillary quantification was assessed blindly. The total number of capillaries in each biopsy was previously assessed by vessel counts in serial sections stained by anti-Von Willebrand factor using the same program. Values were expressed as means \pm S.E.M. 
Immunohistochemical detection of estrogen receptor (ER) $\beta$ was performed on mouse uteri using an anti-ER $\beta$ sheep polyclonal antibody, as previously described (Kurita et al. 2001, Saunders et al. 2001).

\section{Endothelial cell isolation and stimulation}

Endothelial cells (human umbilical vein endothelial cells; HUVEC) were isolated from fresh human umbilical cords using digestion with Collagenase I according to the method of Jaffe et al. (1973). Cells were plated in 0.2\% gelatin-coated flasks. They were grown in Medium 199 supplemented with $20 \%$ fetal calf serum (FCS) and $2 \mathrm{mM}$ glutamine, $100 \mu \mathrm{g} / \mathrm{ml}$ penicillin/streptomycin, $15 \mathrm{mM}$ HEPES and sodium bicarbonate. Cells were cultured in $5 \% \mathrm{CO}_{2}$ at $37^{\circ} \mathrm{C}$ and the media were replaced at 2-day intervals. Immunostaining with Von Willebrand factor antibody (Dako) confirmed their endothelial origin. The presence of Flk-1/KDR was detected by immunostaining of paraformaldehyde-fixed cells with CT128 antibodies, as described above. Second passaged cells were used for experiments. Prior to steroid stimulation, endothelial cells were cultured overnight in a 6-cm Petri dish until confluence in M199 containing 1\% FCS in the absence of steroid (charcoal-stripped serum) and phenol red. For stimulation, the medium was replaced with the same phenol redfree medium containing 5\% serum in the presence of $\mathrm{E}_{2}\left(10^{-10}\right.$ to $\left.10^{-7} \mathrm{M}\right)$ for 3-72 h. Control cells were incubated in phenol red-free medium without hormone.

\section{Cell culture and infection}

Infectious viral particles adr5 (backbone virus), ad-hER $\alpha$ and ad-hER $\beta$ were generated by in vivo recombination of pACsk12 CMV5-hER plasmid with pJM17 in HEK-293 cells, as previously described (Lazennec et al. 2001; Viraquest Inc., North Liberty, IA, USA). Titered virus stock was used to infect HUVEC and HMEC-1 (human microvascular endothelial cells from dermis) using a previously described protocol (Lazennec et al. 2001). Briefly, $10^{6}$ HUVEC or HMEC-1 were seeded in a $60-\mathrm{mm}$ diameter petri dish in 10\% SVF M199 or MCDB 131 respectively. Cells were infected by an adenovirus at a concentration of 100 or 200 pock formit unit/cell for HUVEC and HMEC respectively at $37{ }^{\circ} \mathrm{C}$ in $5 \% \mathrm{CO}_{2}$. Cells were rinsed in PBS and 10\% stripped SVFcontaining medium was added. Cells were treated with various concentrations of $\mathrm{E}_{2}$ for 7 or $24 \mathrm{~h}$ at $37^{\circ} \mathrm{C}$.

\section{$R N A$ extraction and RT-PCR analysis}

Total RNA was isolated from treated or stimulated confluent cultures of human endothelial cells with TriZOL according to the manufacturer's instructions. For the reverse transcription stage, single-stranded cDNA was synthesized from $1 \mu \mathrm{g}$ total RNA in the MMLV reverse transcriptase and hexamers primers. The presence of mRNA encoding the VEGF receptors and estrogen receptors (ER) in endothelial cells was determined using reverse transcriptase-polymerase chain reaction (RT-PCR) and specific oligonucleotide primers.

Detection of estradiol receptors PCR amplification was performed using $5 \% \mathrm{RT}$ product and primers chosen at positions 598-623 and 1392-1416 in human ER $\alpha$ cDNA and positions 124-146 and 498-519 in human ER $\beta$ cDNA (Bausero et al. 2000). The PCR products are 395 and $818 \mathrm{bp}$ for $\mathrm{ER} \beta$ and $\mathrm{ER} \alpha$ respectively. Glyceraldehyde-3-phosphate dehydrogenase (GAPDH) was used as an internal control (450 bp). Amplification was performed using standard Gibco-BRL PCR buffer with $100 \mathrm{nM}$ dNTP, 50 pmoles primers, $1.5 \mathrm{mM} \mathrm{MgCl} 2$ and $1.2 \mathrm{U}$ Taq polymerase, in a $20 \mu \mathrm{l}$ final volume. The parameters for amplification were: $4 \mathrm{~min}$ at $94^{\circ} \mathrm{C}, 40$ cycles of 30 s at $94{ }^{\circ} \mathrm{C}, 1 \mathrm{~min}$ at $57^{\circ} \mathrm{C}, 1 \mathrm{~min}$ at $72{ }^{\circ} \mathrm{C}$ and a 10 min final extension at $72{ }^{\circ} \mathrm{C}$. Products were separated and visualized in ethidium bromide-stained agarose gels. Quantitative RT-PCR (qPCR) of ER $\alpha$ and ER $\beta$ was also performed using Taqman apparatus, according to a method previously described (Bieche et al. 2001).

Quantification of Flk-1/KDR expression by real time RT-PCR All PCRs for the detection of Flk-1/ KDR were performed using the real-time fluorescence detection method with the LightCycler System and a FirstStart DNA Master SYBR Green I kit (Roche Diagnostic, Meylan, France). The primer sequences for Flk-1/KDR were as follows: forward, 5' TCTCAATGT GGTCAACCTTCTAG; reverse, 5' TTTAAACGTCT TAAGGGTGTTAGTG. To avoid amplification of contaminating genomic DNA, two primers were chosen in two different exons. The cycling conditions were as follows: initial denaturation at $95^{\circ} \mathrm{C}$ for $10 \mathrm{~min}$, followed by 40 amplification cycles at $95^{\circ} \mathrm{C}$ for $15 \mathrm{~s}, 55^{\circ} \mathrm{C}$ for $5 \mathrm{~s}$, and $72{ }^{\circ} \mathrm{C}$ for $20 \mathrm{~s}$. A negative control without the cDNA template was performed to assess the overall specificity. Expression levels were normalized to $\beta 2$-microglobulin, which was unaffected in the different treatment groups. Results are expressed as the mean of 5 independent experiments assayed in duplicate.

\section{Statistical analysis}

Student's $t$-test was used to determine the significance between treated and untreated cells, and $P<0.05$ was considered significant.

\section{Results}

Estradiol induces Flk-1/KDR expression in vivo

We have previously described the presence and modulation of VEGF and its Flk-1/KDR receptor in the human 

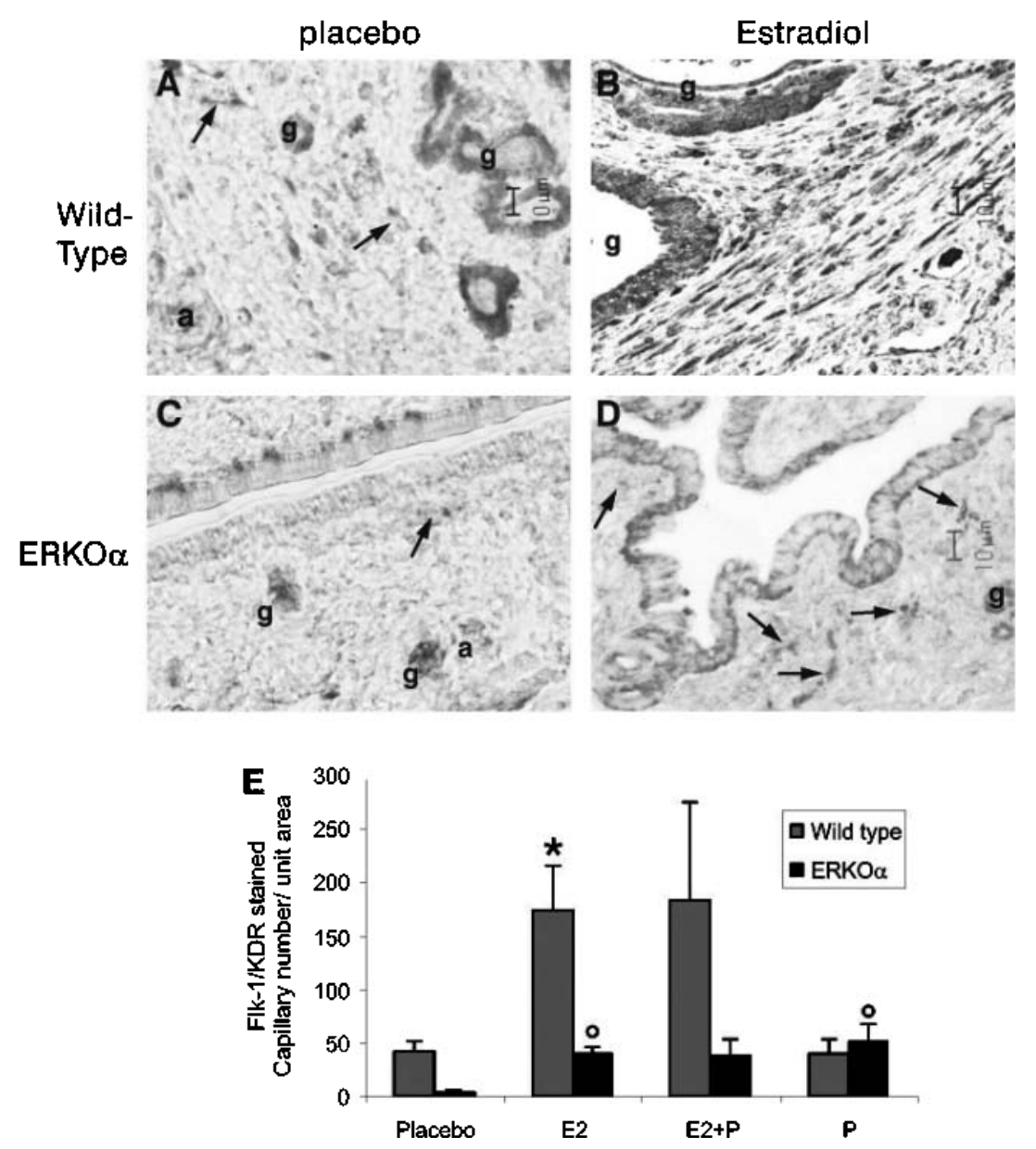

Figure 1 Endothelial Flk-1/KDR expression in mice uterus: immunocytochemical detection. Endometrial sections of ovariectomized (A, B) or $\alpha$ ERKO (C, D) mice were immunostained with anti-Flk-1/KDR antibodies. (A) Untreated wild-type mice; (B) $\mathrm{E}_{2}$-treated wild-type mice; (C) untreated $\alpha E R K O$ mice; (D) $E_{2}$-treated $\alpha E R K O$ mice. Note the immunolabeling in capillaries (arrows) and arterioles (a). The glandular epithelium (g) was also labeled, as previously described in human endometrium (Meduri et al. 2000). Note also the tortuous glandular lining in $\alpha$ ERKO mice in the presence of estradiol (Fig. 1D). Additionally, numerous elongated cells $(20-30 \%)$ were stained for Flk-1/KDR in the endometrial stroma of $E_{2}$-treated animals as compared with control animals. Original magnification, $\times 400$. $(E)$ Quantitative analysis of the number of capillaries expressing Flk-1/KDR in mouse uteri. Ovariectomized wild-type or $\alpha$ ERKO mice were treated or not with $E_{2}(E 2)$, progesterone (P) or $E_{2}+$ progesterone $(E 2+P)$ over 21 days, as described above. The number of Flk-1/KDR-stained capillaries \pm S.E.M. is shown. ${ }^{\star} P<0.05$ placebo versus $E_{2}$ in wild-type mice; ${ }^{\circ} P<0.05$ placebo versus $E_{2}$ or $P$ in $\alpha E R K O$ mice. It is interesting to note that progesterone alone also increased Flk-1/KDR in $\alpha \mathrm{ERKO}$ mice, in a similar manner to $\mathrm{E}_{2}$.

cyclic endometrium (Meduri et al. 2000). The expression of this receptor, deduced from the semi-quantitative analysis of capillaries immunostained for Flk-1/KDR, was maximal in the proliferative and in the mid-secretory periods. This observation suggests a possible effect of $E_{2}$ on the expression of Flk-1/KDR in the endometrium.

In order to assess the possible effect of $E_{2}$ on Flk-1/ $\mathrm{KDR}$ expression in vivo, we have chosen the mouse uterus model. Ovariectomized mice were treated with
$\mathrm{E}_{2}$ or vehicle, as described in Materials and Methods, and uterine sections were immunostained for Flk-1/KDR (Fig. 1A-D). Quantification of VEGF receptor was examined using a protocol previously described by Meduri et al. (2000). Morphometric analysis showed a significant increase in the number of Flk-1/KDR-stained vascular structures expressed per unit area in the uteri of $\mathrm{E}_{2}$-treated (4.1-fold induction, $P<0 \cdot 05)$ or $\mathrm{E}_{2}+$ progesterone-treated (4.3-fold induction, $P<0 \cdot 05)$ mice as compared with 


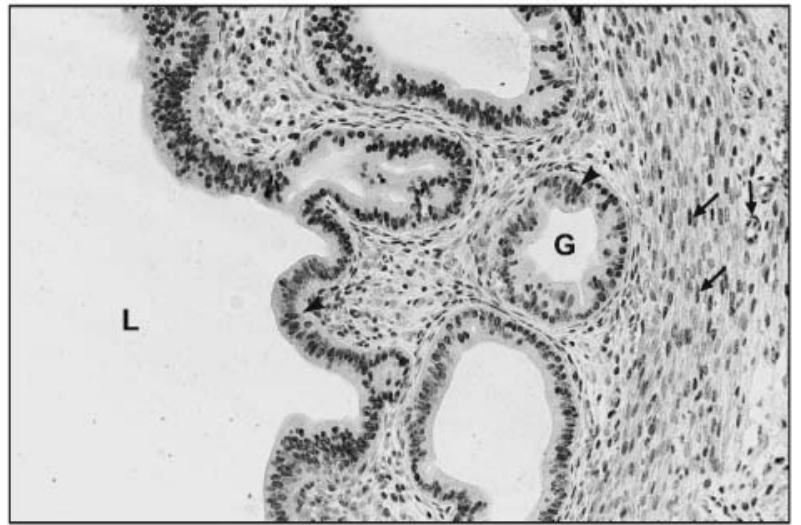

Figure 2 Expression of ER $\beta$ in mouse uterus. Uterine sections were immunostained with anti-ER $\beta$ antibodies (Saunders et al. 2001). ER $\beta$-positive cells are seen in epithelial (arrowheads) and endothelial (open arrow) cells, as well as in some stromal cells (arrows). G, gland; L, lumen. Original magnification, $\times 20$. Insert, high magnification of an immunostained vessel (open arrow).

controls. In contrast, there was no change in the expression of Flk-1/KDR in wild-type progesterone-treated mice (Fig. 1E).

In order to analyze the mechanism of $\mathrm{E}_{2}$ up-regulation of Flk-1/KDR in mice uteri, similar experiments were performed in $\mathrm{E}_{2}$-treated mice with a disruption of the $\mathrm{ER} \alpha$ gene $(\alpha \mathrm{ERKO}$ mice) (Fig. 1C,D). As shown in Fig. 1E, the number of uterine Flk-1/KDR expressing vascular structures was significantly lower in $\mathrm{E}_{2}-$ or $\mathrm{E}_{2}+$ progesterone-treated $\alpha \mathrm{ERKO}$ mice as compared with $\mathrm{E}_{2}$-treated wild-type mice $(P<0 \cdot 05)$, suggesting that ER $\alpha$ could be involved in this regulation process. However, the number of Flk-1/KDR stained vascular structures was also lower in untreated $\alpha$ ERKO mice versus untreated wild-type mice $(P<0 \cdot 05)$ (Fig. 1E). Also, $\mathrm{E}_{2}$ or $\mathrm{E}_{2}+$ progesterone significantly increased Flk-1/KDR expression in $\alpha$ ERKO mice $(P<0 \cdot 06)$, suggesting that ER $\beta$ could also be involved in this regulation. As shown in Fig. 2 , endothelial cells from mouse uteri do express ER $\beta$, similar to the situation described in human uteri (Lecce et al. 2001). Altogether, our in vivo data show that $\mathrm{E}_{2}$ increases Flk-1/KDR expression via estrogen receptor $(\alpha$ or $\beta$ ) activation. Comparative experiments using immunostaining with anti-vWF ( a marker of endothelial cells) indicate that $\mathrm{E}_{2}$-treatment of mice results in an increase in the total number of blood vessels, but not in an increase in the number of blood vessels expressed per unit area (not shown). Therefore, the increase in Flk-1/KDR-positive blood vessels of $\mathrm{E}_{2}$-treated mice does not result from an overall increase in blood vessels.

The $\mathrm{E}_{2}$-induced Flk-1/KDR expression observed in vivo could result either from a direct effect of $\mathrm{E}_{2}$ on endothelial cells, or from an indirect effect through the secretion of VEGF by surrounding cells.
A

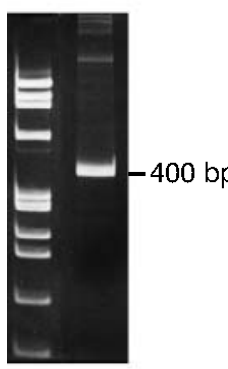

B

C

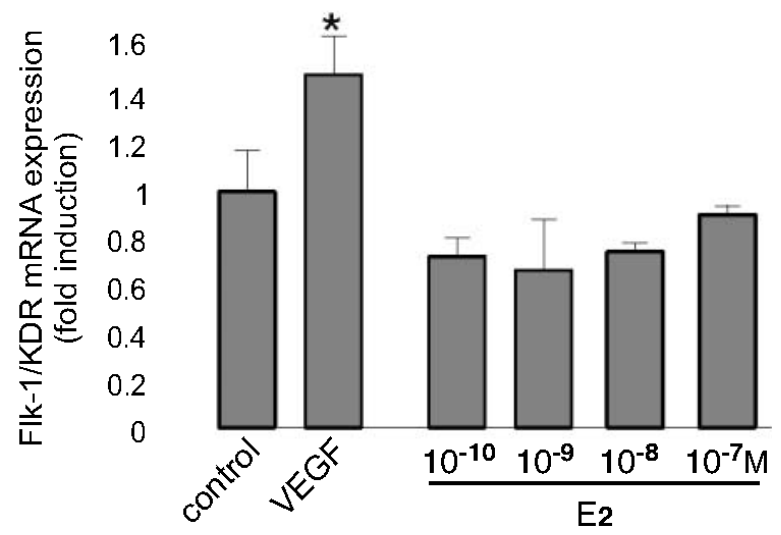

Figure 3 VEGF, but not $E_{2}$, up-regulates Flk-1/KDR expression. (A, B) HUVEC (passage 2) express Flk-1/KDR receptors, as shown by RT-PCR analysis (A) and immunocytochemistry with monoclonal anti-Flk-1/KDR antibodies (CT128 clone) and biotinylated fluorescein-streptavidin (B). Note in (B) that Flk-1/KDR is mainly detected at the plasma membrane level and in the cytoplasm. Original magnification, $\times 40$. (C) VEGF up-regulates Flk-1/KDR expression. HUVEC were treated with VEGF $(10 \mathrm{ng} / \mathrm{ml})$ or $\mathrm{E}_{2}$ $\left(10^{-10}\right.$ to $\left.10^{-7} \mathrm{M}\right)$ for $7 \mathrm{~h}$. Relative RNA units for Flk-1/KDR were normalized with the $\beta 2$-microglobulin level, as calculated from standard curves, and compared with untreated cells. The results are expressed as the mean \pm S.E.M. of three experiments. ${ }^{*} P<0.05$ compared with untreated control cells.

VEGF, but not estradiol, increases Flk-1/KDR expression in endothelial cells (HUVEC)

VEGF levels have previously been shown to increase in human uterine cells in response to $\mathrm{E}_{2}$ stimulation (Shifren et al. 1996, Bausero et al. 1998). In order further to analyze the possible effects of $E_{2}$ and VEGF on Flk-1/KDR expression in vitro, we used endothelial cells prepared from umbilical cord (HUVEC). As shown by immunofluorescence and RT-PCR analysis, these cells expressed Flk-1/KDR receptor (Fig. 3A,B).

The modulation of Flk-1/KDR expression by $\mathrm{E}_{2}$ and VEGF was further analyzed using quantitative real-time PCR analysis and a LightCycler protocol developed as described in Materials and Methods. This allows the sensitive, specific and quantitative detection of VEGF receptor. 

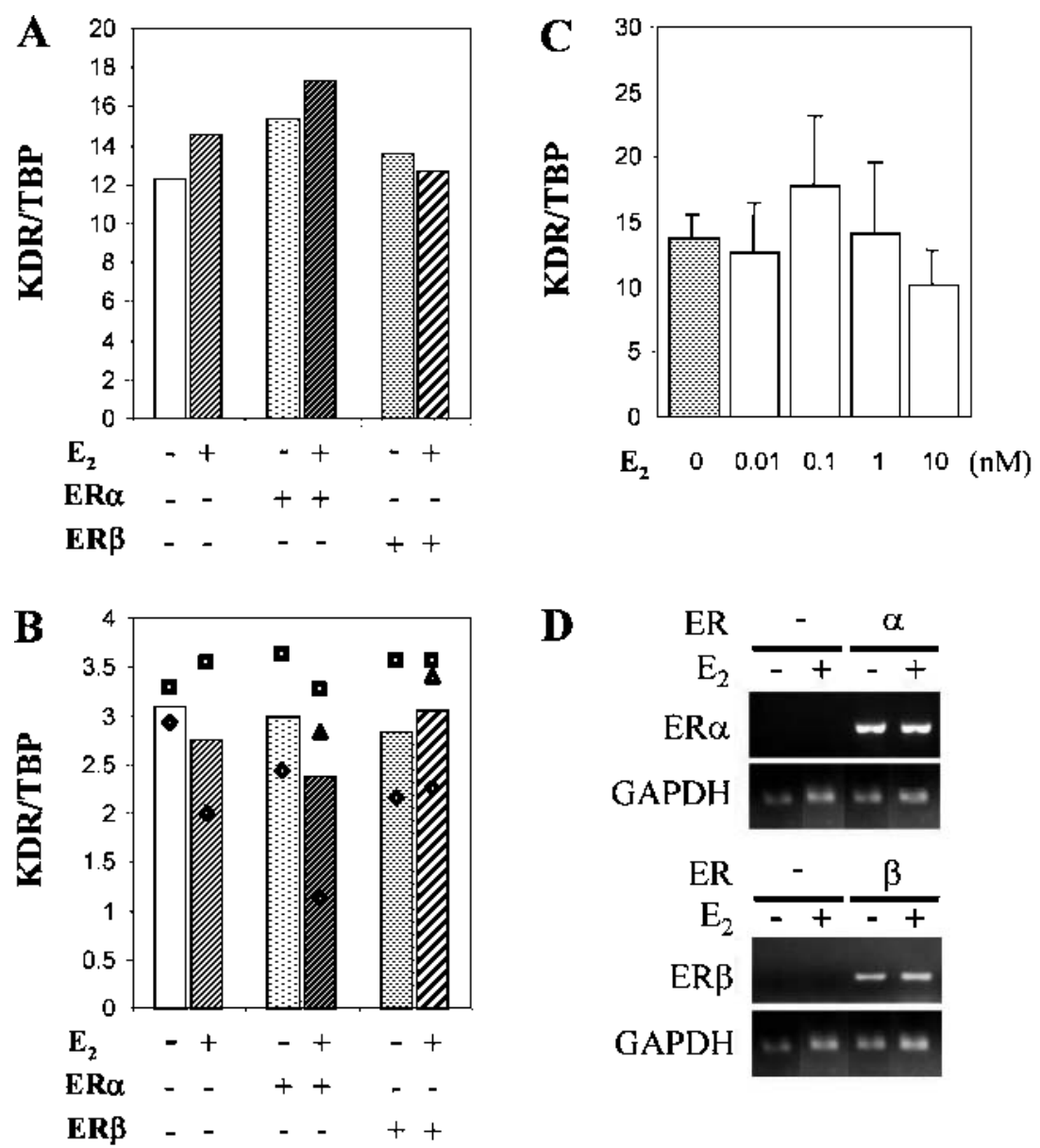

$\mathbf{D}$

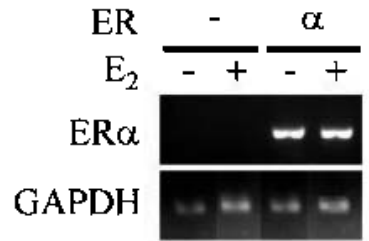

Figure $4 \mathrm{E}_{2}$ does not modulate Flk-1/KDR gene expression in endothelial cells that overexpress ER $\alpha$ or ER $\beta$. (A) The HMEC-1 cell line and (B) primary HUVEC were infected overnight with $\mathrm{Ad} 5, \mathrm{Ad}-\mathrm{ER} \alpha$ or Ad-ER $\beta$ viruses $48 \mathrm{~h}$ prior to RNA isolation. Cells were treated with $100 \%$ ethanol ( - ) or $10 \mathrm{nM} \mathrm{E}_{2}(+)$ for $7 \mathrm{~h}$. (C) HMEC-1 cells infected by Ad-ER $\beta$ virus were treated or not with different concentrations of $E_{2}(n M)$ for $24 \mathrm{~h}$. Flk-1/KDR mRNA levels were measured by real-time quantitative RT-PCR and were normalized to TATA Box binding protein (TBP) mRNA levels. Results represent one experiment in $(A)$, and the mean of two or three independent experiments in (B) and (C). (D) Adenoviral expression of ER $\alpha$ and ER $\beta$ in HUVEC infected with Ad5, Ad-ER $\alpha$ or Ad-ER $\beta$ viruses, as checked by RT-PCR. Cells were treated (+) or not $(-)$ with $10 \mathrm{nM} \mathrm{E}_{2}$ for $7 \mathrm{~h}$. The PCR products have a size of $818 \mathrm{bp}, 395 \mathrm{bp}$ and $450 \mathrm{bp}$ for ER $\alpha$, ER $\beta$ and GAPDH respectively. Panel D shows a representative experiment.

Stimulation of HUVEC by VEGF $(10 \mathrm{ng} / \mathrm{ml})$ significantly increased the level of Flk-1/KDR mRNA over control values (Fig. 3C). The increase in Flk-1/KDR expression by VEGF was dose- and time-dependent (not shown), with a maximal effect at $10 \mathrm{ng} / \mathrm{ml}$ and $7 \mathrm{~h}(1 \cdot 5$-fold induction, $P<0 \cdot 05$ ) (Fig. 3C). VEGF increased Flk-1/ KDR expression in all HUVEC samples tested $(n=7)$.

Treatment of HUVEC endothelial cells with $\mathrm{E}_{2}\left(10^{-10}\right.$ to $10^{-7} \mathrm{M}$ ) for $7 \mathrm{~h}$ (Fig. $3 \mathrm{C}$ ) or with $10^{-8} \mathrm{M}$ for $0-72 \mathrm{~h}$ (not shown) did not induce significant Flk-1/KDR expression. Using quantitative RT-PCR analysis (Bieche et al. 2001), ER $\alpha$ was absent in all HUVEC samples $(n=7)$, while ER $\beta$ was present in very low amounts (not shown) with values always set below the lowest range (below the first tertile) found using the same method in a series of 131 primary breast cancer tumors (Bieche et al. 2001). The absence of an effect of $E_{2}$ on Flk-1/KDR expression in HUVEC could be explained by a loss of ER expression in the primary endothelial cells when isolated from the umbilical cord. Therefore, we have overexpressed ER $\alpha$ or ER $\beta$ in macro- (HUVEC) and micro- (HMEC-1) vascular cells, using adenovirus infection as described in Materials and Methods (see Fig. 4D) and have analyzed the modulation of Flk-1/KDR in 
these cells (Fig. 4A-C). Results indicate that $\mathrm{E}_{2}$ does not affect the Flk-1/KDR expression in endothelial cells, whether $\mathrm{E}_{2}$ was used at $10^{-8} \mathrm{M}$ (Fig. $4 \mathrm{~A}, \mathrm{~B}$ ) or at various concentrations (Fig. 4C).

Altogether, these results suggest that the regulation of Flk-1/KDR expression by $\mathrm{E}_{2}$ in endothelial cells does not involve an autocrine mechanism and mainly occurs through the VEGF pathway.

\section{Discussion}

VEGF is a key mediator of angiogenesis. Its expression, abundant in the embryo, is down-regulated in the adult, except during cyclical endometrial growth and corpus luteum formation (Ferrara \& Davis-Smyth 1997, Perrot-Applanat 2000). Alterations in the expression of VEGF and its receptors are associated with disruption of ovarian and uterine functions (Ferrara et al. 2003). Despite the biological relevance of Flk-1/KDR in angiogenesis, little is known about the molecular mechanisms controlling its expression. In the present work, we describe the up-regulation of Flk-1/KDR by $\mathrm{E}_{2}$ in vivo in the mouse endometrium, while experiments on endothelial cells in vitro show the up-regulation of Flk-1/KDR by VEGF in the absence of a direct $\mathrm{E}_{2}$ effect, suggesting a paracrine mechanism of regulation of Flk-1/KDR in vivo.

In vivo regulation of Flk-1/KDR expression by $E_{2}$ in the uterus

Endometrial cyclical growth depends on capillary proliferation and increased blood flow caused by vasodilatation and changes in vascular permeability (Giudice 1996). These changes are regulated by $\mathrm{E}_{2}$ and progesterone through activation of their respective nuclear receptors (Perrot-Applanat et al. 1994, Lecce et al. 2001). E directly modulates VEGF expression in the human endometrium in vivo (Shifren et al. 1996, Bausero et al. 1998). Preliminary observations suggest that $\mathrm{E}_{2}$ also modulates endometrial Flk-1/KDR (Meduri et al. 2000), essential for the development of the uterine vasculature during physiological angiogenesis (Heryanto et al. 2003). However, the mechanisms controlling $\mathrm{E}_{2}$-induced Flk-1/KDR expression are unclear. As functional ERs are essential for the $\mathrm{E}_{2}$-induced increase in angiogenesis, wild-type and $\alpha$ ERKO mice (Couse et al. 1995) provide a valuable model to examine the ER-mediated estrogenic effect on uterine Flk-1/KDR expression. We quantified Flk-1/ $\mathrm{KDR}$ expression in ovariectomized wild-type or $\alpha \mathrm{ERKO}$ $\mathrm{E}_{2}$-treated mice using an established protocol (Meduri et al. 2000). Our data show that $\mathrm{E}_{2}$ induces Flk-1/KDR expression through functional $\mathrm{ER} \alpha$ activation in the mouse uterus, as previously suggested for the human endometrium (Meduri et al. 2000). From our data, ER $\alpha$ does not seem to be the only mediator for Flk-1/KDR expression.
Since ER $\beta$ is also expressed in uterine endothelial cells, we can anticipate a possible role for ER $\beta$ in $E_{2}$-induced Flk-1/KDR expression in the absence of $\operatorname{ER} \alpha$. This hypothesis could be strengthened by the study of Kurita et al. (2001), who has previously described a role for ER $\beta$ in $E_{2}$ induction of progesterone receptor in $\alpha E R K O$ mice. Further experiments using mice with $\operatorname{ER} \beta$ invalidation are required to elucidate the respective roles of $\operatorname{ER} \alpha$ and $\mathrm{ER} \beta$ in Flk-1/KDR induction.

We have shown that progesterone modulates VEGF secretion in decidual cells (Ancelin et al. 2002). While adjunction of progesterone does not modify the $\mathrm{E}_{2}$ effect on Flk-1/KDR expression in wild-type and $\alpha \mathrm{ERKO}$ mice, progesterone alone increases Flk-1/KDR expression only in $\alpha E R K O$ but not in wild-type mice (see Fig. 1). We do not know why progesterone has an effect only in the absence of ER $\alpha$. Previous studies have demonstrated the presence of progesterone receptors in $\alpha$ ERKO mice; progesterone is able to induce a decidual reaction and to regulate gene expression in these animals (Curtis et al. 1999). Our data on the role of progesterone in Flk-1/KDR expression in the mouse uterus need to be confirmed on a larger series of animals.

\section{$E_{2}$ and in vitro regulation of Flk-1/KDR expression in endothelial cells}

Experimental studies show that $\mathrm{E}_{2}$ exerts direct effects on endothelial cells, including up-regulation of endothelial nitric oxide synthase activity, modulation of adhesion molecule expression, angiogenic activity and proliferation in vitro after 6 days of culture (Morales et al. 1995). However, it is unclear whether these effects are mediated through modulation of VEGF receptors. In our study, $\mathrm{E}_{2}$ did not increase significantly Flk-1/KDR expression in HUVEC samples from early passages (P1 to P2). A small increase in Flk-1/KDR expression with $\mathrm{E}_{2}$ was observed in one of the 7 samples analyzed (not shown), which could be mediated by $\operatorname{ER} \beta$, as suggested by the presence of low levels of ER $\beta$. The presence of ER $\beta$, but not of ER $\alpha$ mRNA, was previously described in HUVEC (Enmark et al. 1997, Stefano et al. 2000). Our results could be interpreted by the fact that the response could vary among different subjects, or by a loss of ER expression in most samples. Gargett et al. (2002) report a moderate increase in Flk-1/KDR expression in $\mathrm{E}_{2}$-treated myometrial endothelial cells, mediated primarily by ER $\alpha$. These discrepancies may reflect differences in endothelial cell origin and/or conditions of culture such as the number of passages. We and others have detected only ER $\beta$ and not $\mathrm{ER} \alpha$ in human and mouse endothelial cells in vivo (Critchley et al. 2001, Kurita et al. 2001, Lecce et al. 2001, as shown in this study). To counteract the loss of ER expression in our primary endothelial cells, HUVEC, we have overexpressed ER $\alpha$ or ER $\beta$ in macro- (HUVEC) and micro- (HMEC-1) vascular cells. Our results show 
that $\mathrm{E}_{2}$ does not modulate $\mathrm{Flk}-1 / \mathrm{KDR}$ expression in endothelial cells. In our studies, we have also used transient transfection of $\operatorname{ER} \alpha$ and $\operatorname{ER} \beta$ cDNA along with a Flk-1/KDR promoter-luciferase gene reporter in an umbilical cord cell line (HUV-E-C), which expresses low levels of Flk-1/KDR, as compared with primary HUVEC. $\mathrm{E}_{2}$ did not activate Flk-1/KDR in these cells but activated an estrogen response element luciferase construct (data not shown). Thus, $\mathrm{E}_{2}$ does not directly modulate Flk-1/KDR in endothelial cells; a direct effect of $\mathrm{E}_{2}$ could be limited to the vasculature of sex steroid-responsive tissues, such as the myometrium.

\section{VEGF induces up-regulation of Flk-1/KDR in vitro and in vivo}

Previous studies have demonstrated that $\mathrm{E}_{2}$ increases VEGF secretion in human and animal uterine cells (Cullivan-Bove \& Koos 1993, Shifren et al. 1996, Bausero et al. 2000). The present study demonstrates a VEGFinduced up-regulation of Flk-1/KDR mRNA in endothelial cells (HUVEC), in agreement with a previous study on the capillary endothelium of bovine adrenal cortex (Shen et al. 1998). By qPCR we can barely detect VEGF mRNA in HUVEC (unpublished results). Altogether, these results suggest that VEGF cannot stimulate Flk-1/ KDR via an autocrine mechanism. Up-regulation of Flk-1/KDR protein levels was also reported in other studies using either endothelial cells from human saphenous veins infected with an adenoviral vector encoding VEGF165 (Weisz et al. 2001), or mouse cerebral slices incubated with recombinant VEGF165 (Kremer et al. 1997). These data suggest that Flk-1/KDR is regulated by VEGF synergistically with other factors, such as transforming growth factor- $\beta$, tumor necrosis factor- $\alpha$ and shear stress (Ferrara \& Davis-Smyth 1997, Shen et al. 1998).

The up-regulation of VEGF expression by $E_{2}$ has been established in vivo in the injured-carotid model of angiogenesis in which $\mathrm{E}_{2}$ increases re-endothelialization (Concina et al. 2000) while a direct modulation of Flk-1/ KDR appears to be very inconsistently observed, suggesting that, in this model also, $\mathrm{E}_{2}$ regulates angiogenesis mainly through a paracrine VEGF action.

In conclusion, we describe the effects of $\mathrm{E}_{2}$ on the increase in Flk-1/KDR expression in a sex steroidresponsive tissue - the human and mouse uterus. The increase in Flk-1/KDR expression by $\mathrm{E}_{2}$ leading to an increase in angiogenesis is secondary to an $\mathrm{E}_{2}$ up-regulation of VEGF expression, previously observed in vivo, associated with VEGF-induced Flk-1/KDR expression in endothelial cells as shown in this study.

\section{Funding}

The authors declare that there is no conflict of interest that would prejudice the impartiality of this scientific work.

\section{Acknowledgements}

We thank Dr Ken Korach and Sylvia Hewitt (Triangle Park, USA) for the gift of knock-out animals, Dr Philippa Saunders (Edingburg, Scotland) for anti-ER $\beta$ antibodies and the immunostaining of $\operatorname{ER} \beta$ in mouse uteri. We also thank Dr Frederique Spyratos (Centre René Huguenin, Saint Cloud, France) for real-time PCR quantification of ER.

\section{References}

Abumiya T, Sasaguri T, Taba Y, Miwa Y \& Miyagi M 2002 Shear stress induces expression of vascular endothelial growth factor receptor Flk-1/KDR through the CT-rich $\mathrm{Sp} 1$ binding site. Arteriosclerosis Thrombosis Vascular Biology 22 907-913.

Ancelin M, Buteau-Lozano H, Meduri G, Osborne-Pellegrin M, Sordello S, Plouet J \& Perrot-Applanat M 2002 A dynamic shift of VEGF isoforms with a transient and selective progesterone-induced expression of VEGF189 regulates angiogenesis and vascular permeability in human uterus. PNAS 99 6023-6028.

Bausero P, Freitas S, Meduri G \& Perrot-Applanat M 1998 Paracrine action of VEGF in the human endometrium: regulation by ovarian steroids. Angiogenesis 2 167-182.

Bausero P, Mazucatelli JP, Bloy C \& Perrot-Applanat M 2000 Estradiol, tamoxifen and hypoxia modulate vascular endothelial growth factor in human vascular smooth muscle cells. American Journal of Physiology 2033-2042.

Bieche I, Parfait B, Nogues C, Andieu C, Vidaud D, Spyratos F, Lidereau R \& Vidaud M 2001 The CGA gene as new predictor of the response to endocrine therapy in ER alpha-positive postmenopausal breast cancer patients. Oncogene 20 6955-6959.

Concina P, Sordello S \& Barbacanne MA 2000 The mitogenic effect of 17 beta-estradiol on in vitro endothelial cell proliferation and on in vivo re-endothelialization are both dependent on vascular endothelial growth factor. Journal of Vascular Research 37 202-208.

Couse JF, Curtis SW, Washburn TF, Eddy EM, Schomberg DW \& Korach KS 1995 Disruption of the mouse oestrogen receptor gene: resulting phenotypes and experimental findings. Biochemical Society of Transplantation 23 929-935.

Critchley HOD, Brenner RM, Henderson TA, Williams K, Nayak NR, Slayden OD, Millar MR \& Saunders PTK 2001 Estrogen receptor beta, but not estrogen receptor alpha, is present in the vascular endothelium of the human and nonhuman primate endometrium. Journal of Clinical Endocrinology and Metabolism $\mathbf{8 6}$ 1370-1378.

Cullivan-Bove K \& Koos RD 1993 Vascular endothelial growth factor/vascular permeability factor expression in the rat uterus: rapid stimulation by estrogen correlates with estrogen-induced increases in uterine capillary permeability and growth. Endocrinology 133 829-837.

Curtis S, Clark J, Myers P \& Korach K 1999 Disruption of estrogen signaling does not prevent progesterone action in the estrogen receptor $\alpha$ knockout mouse uterus. PNAS 96 3646-3651.

Enmark E, Pelto-Huikko M, Grandien K, Lagercrantz S, Lagercrantz J, Fried G, Nordenskjöld M \& Gustafsson 1997 Human estrogen receptor $\beta$ gene structure, chromosomal localisation, and expression pattern. Journal of Clinical Endocrinology 82 4258-4265.

Ferrara N \& Davis-Smyth T 1997 The biology of vascular endothelial growth factor. Endocrinology Review 18 4-25.

Ferrara N, Gerber HP \& LeCouter J 2003 The biology of VEGF and its receptors. Nature Medicine 9 669-676.

Gargett CE, Zaitseva M, Bucak K, Chu S, Fuller PJ \& Rogers PA 2002 17-Beta-estradiol up-regulates vascular endothelial growth 
factor receptor-2 expression in human myometrial microvascular endothelial cells: role of estrogen receptor-alpha and -beta. Journal of Clinical Endocrinology and Metabolism 87 4341-4349.

Gille H, Kowalski J, Li B, LeCouter J, Moffat B, Zioncheck TF, Pelletier N \& Ferrara N 2001 Analysis of biological effects and signaling properties of Flt-1 (VEGFR-1) and KDR (VEGFR-2). A reassessment using novel receptor-specific vascular endothelial growth factor mutants. Journal of Biological Chemistry $\mathbf{2 7 6}$ $3222-3230$

Giudice L 1996 The endometrial cycle. In Reproductive Endocrinology, Surgery and Technology, pp 272-300. Eds EY Adashi, JA Rock \& Z Rosenwaks. Philadelphia: Lippincolt-Raven Publishers.

Heryanto B, Lipson KE \& Rogers PA 2003 Effects of angiogenesis inhibitors on oestrogen-mediated endometrial endothelial cell proliferation in the ovariectomized mouse. Reproduction 125 337-346.

Jaffe EA, Nachman RL, Becker CG \& Minick CR 1973 Culture of human endothelial cells derived from umbilical veins. Identification by morphologic and immunologic criteria. Journal of Clinical Investigation $\mathbf{5 2} 2745-2756$.

Kremer C, Breier G, Risau W \& Plate KH 1997 Up-regulation of Flk-1/vascular endothelial growth factor receptor 2 by its ligand in a cerebral slice culture system. Cancer Research 57 3852-3859.

Kurita T, Lee K, Saunders PT, Cooke PS, Taylor JA, Lubahn DB, Zhao C, Makela S, Gustafsson JA, Dahiya R \& Cunha GR 2001 Regulation of progesterone receptors and decidualization in uterine stroma of the estrogen receptor-alpha knockout mouse. Biology of Reproduction 64 272-283.

Lazennec G, Bresson D, Lucas A, Chauveau C \& Vignon F 2001 ER beta inhibits proliferation and invasion of breast cancer cells. Endocrinology 142 4120-4130.

Lecce G, Meduri G, Ancelin M, Bergeron C \& Perrot-Applanat M 2001 Presence of estrogen receptor beta in the human endometrium through the cycle: expression in glandular, stromal, and vascular cells. Journal of Clinical Endocrinology and Metabolism 86 1379-1386.

Meduri G, Bausero P \& Perrot-Applanat M 2000 Expression of vascular endothelial growth factor receptors in the human endometrium: modulation during the menstrual cycle. Biology of Reproduction 62 439-447.

Millauer B, Wizigmann-Voos S, Schnurch H, Martinez R, Moller NP, Risau W \& Ullrich A 1993 High affinity VEGF binding and developmental expression suggest Flk-1 as a major regulator of vasculogenesis and angiogenesis. Cell 72 835-846.
Morales DE, McGowan KA, Grant DS, Maheshwari S, Bhartiya D, Cid MC, Kleinman HK \& Schnaper HW 1995 Estrogen promotes angiogenic activity in human umbilical vein endothelial cells in vitro and in a murine model. Circulation 91 755-763.

Perrot-Applanat M 2000 Hormonal regulation of vascular cell function: angiogenesis. In Encyclopedic Reference of Vascular Biology and Pathology pp 157-162. Ed A Bikfalvi. Heidelberg: Springer Verlag.

Perrot-Applanat M, Deng M, Fernandez H, Lelaidier C, Meduri G \& Bouchard P 1994 Immunohistochemical localization of estradiol and progesterone receptors in human uterus throughout pregnancy: expression in endometrial blood vessels. Journal of Clinical Endocrinology and Metabolism 78 216-224.

Saunders PTK, Millar MR, Williams K, Macpherson S, Harkiss D, Anderson RA, Orr B, Groome NP, Scobie G \& Fraser HM 2001 Differential expression of estrogen receptor ER $\alpha$ and $\operatorname{ER} \beta$ and androgen receptor in the ovaries of marmosets and humans. Biology of Reproduction 63 1098-1105.

Shen BQ, Lee DY, Gerber HP, Keyt BA, Ferrara N \& Zioncheck TF 1998 Homologous up-regulation of KDR/Flk-1 receptor expression by vascular endothelial growth factor in vitro. Journal of Biological Chemistry 273 29979-29985.

Shifren JL, Tseng JF \& Zaloudek CJ 1996 Ovarian steroid regulation of vascular endothelial growth factor in the human endometrium: implications for angiogenesis during the menstrual cycle and in the pathogenesis of endometriosis. Journal of Clinical Endocrinology and Metabolism 81 3112-3118.

Spyridopoulos I, Sullivan AB, Kearney M, Isner JM \& Losordo DW 1997 Estrogen receptor-mediated inhibition of human endothelial cell apoptosis. Estradiol as a survival factor. Circulation 95 1505-1514.

Stefano GB, Prevot V, Beauvillain JC, Cadet P, Fimiani C, Welters I, Fricchione GL, Breton C, Lassalle P, Salzet M \& Bilfinger TV 2000 Cell-surface estrogen receptors mediate calcium-dependent nitric oxide release in human endothelia. Circulation 101 1594-1597.

Weisz A, Koren B, Cohen T, Neufeld G, Kleinberger T, Lewis BS \& Flugelman Y 2001 Increased vascular endothelial growth factor 165 binding to kinase insert domain-containing receptor after infection of human endothelial cells by recombinant adenovirus encoding the VEGF $_{165}$ gene. Circulation 103 1887-1892.

Received 16 September 2005

Accepted 17 October 2005

Made available online as an Accepted Preprint 3 November 2005 